\title{
Software Design using Visual Basic for Application and Microsoft Excel Programming for Students
}

\author{
FADILLAH RAMADHAN, HENDANG SETYO RUKMI, ARIF IMRAN, CAHYADI \\ NUGRAHA, RISDAN FERDIANSYAH
}

\author{
Department of Industrial Engineering, Institut Teknologi Nasional Bandung \\ Email: f.ramadhan@itenas.ac.id
}

Received 27 November 2020 | Revised 29 November 2020 | Accepted 30 November 2020

\begin{abstract}
The rapid development of information technology has made people to have the ability to design software with a programming language. There are quite some engineers who have not mastered programming languages. It happens because some people think that developing software with a certain programming language is very difficult. The language is difficult to understand, the accuracy must be precise, and the user is not familiar with the platform. Difficulty in learning programming languages is a problem that is often encountered by university students, vocational students, or employees. This article describes an easy programming language training activity for beginners, namely Visual Basic for Applications (VBA) - Ms. Excel training. The advantage of this programming language is easy to operate because many students or employees are very familiar with Ms. Excel so that the adaptation process will be easy. The results of the post-test training that was attended by students showed a significant increase in the ability to design programming languages.
\end{abstract}

Keywords: Ms. Excel, programming, software, training, VBA

\section{INTRODUCTION}

The need for competencies related to information technology is growing rapidly (Liu, Wei, Ke, Wei, \& Hua, 2016; Perez-Lopez \& Alegre, 2012). This was followed by the development of information technology from various fields which made people to have the ability to design software with a programming language. The development of technology towards a new industrial revolution makes information technology no longer only belongs to various engineers who focus on hardware and software, but now the ability to design information technology is a necessity for all fields (Fisher, 1996; Sa'ari, Luan, \& Samsilah, 2005). The ability to develop programming languages is one of the important aspects of designing information technology, and this is not yet a priority competence.

There are quite some engineers who have not mastered a programming language to create computational tools that can help their work. Difficulty in learning programming languages is 
Software Design using Visual Basic for Application and Microsoft Excel Programming for Students

the main problem for some people. Difficulty in understanding language, accuracy, even logic 
or an unfamiliar platform makes many of these competencies not fully available (Cazzola \& Olivares, 2016). This problem often encountered both for students who do not focus on information technology or employees who work in companies.

One of the community service partners in developing areas who will be assisted to improve their abilities is STIE DR. KHEZ Muttaqien Purwakarta. This school focuses on two major areas, namely management and accounting. From the curriculum being taught, there is still no focus of study to discuss programming language, even basic programming. However, there are management information systems courses that are studied. This becomes incomplete because in learning management information systems, it is better to understand the basics of programming first. In addition, management or accounting majors will be significantly helped by the existence of software computing tools. For the management part, the software program can be used to build various software, such as document management systems, logistics management, financial management and others, likewise, for the field of accounting which can be used to design financial calculation software and accounting information systems. This becomes an important problem because the need for new and easy-to-learn competencies is an activity that must be added to the school, considering that not many people have competencies in the programming field. Besides university students, vocational schools like a few of SMKs in Purwakarta that have many students that are not familiar in programming language be a part of participants. Vocational students as an applicable resource are also expected to learn programming languages considering that in the manufacturing or service industry, they will be involved with information technology. SMKs students need practical skills such as programming because they are targeted to graduate and are ready to work.

The solution that can be used in dealing with these problems is to learn a programming language that is easy to operate, familiar in terms of appearance, and quite powerful in producing software. Visual Basic for Applications (VBA) - Ms. Excel is a programming language that is integrated into Microsoft Excel (Li, Zhang, Almeev, \& Holtz, 2020; Wong \& Barford, 2010). The advantage of this programming language is easy to operate because many students or employees are very familiar with Ms. Excel so that the adaptation process will be very easy. In addition, various data processing which is usually done by students or employees uses Ms. Excel. By being proficient in operating VBA in Excel, the work of students or employees will be greatly helped. Therefore, VBA-Excel training activities are very useful for beginners who want to learn programming languages in a software environment that is quite easy to understand and familiar in operation.

There is a lot of evidence that VBA-Excel can solve important and useful problems in terms of research or the socio-economic impact of society as has been proven in the Sophan (2014) article regarding the use of Visual Basic in designing a building shop inventory control management information system. Several previous researches related to Visual Basic are proposed by Astuti (2011) for designing drug sales information systems, Saputra (2015) for designing photo studio information systems, Nasikin (2011) for designing Visual Basic for academic information systems, Irmawati \& Indrihapsari (2014) for designing visual basic for company archival information systems, and many others show the use of visual basic language which can be useful for various fields. The use of Visual Basic also published in several international article topics such as complex topics to help make decisions on product criteria selection (Hyde \& Maier, 2006), implementation of visual basic in irrigation cases (Valipour \& Montazar, 2012), and visual basic for analyzing geochemical (Nakic, Posavec, \& Bacani, 2007). 
Software Design using Visual Basic for Application and Microsoft Excel Programming for Students

Therefore, this article describes the VBA-Excel training activities carried out for participants consisting of university and vocational students. This training aims to spread knowledge and 
technology in increasing the competitiveness of information technology capabilities in developing areas. More and more creative people in designing programming languages among academics, SMEs, and large companies can increase people's readiness to face the new industrial revolution from the field of information technology. For the industrial sector, this is very useful where potential resources are equipped with a good programming language so that it can increase the readiness and performance of the industry itself.

\section{METHOD}

Training activities have been carried out online using google meet, where participants only need a laptop/PC to interact online as well as the installed Ms. Office Excel software. Direct tutorial learning method was given, which begins with a brief theoretical explanation followed by direct application to VBA-Excel. The tutor explains the coding process which the participants immediately follow. Before doing tutorial activities, there was a pre-test related to program understanding in a basic manner. This pre-test aims to measure the initial abilities of the participants. At the end of the session, participants knowledge have been measured again through a post-test. From the results of the test, it will assess how much the participants will absorb the material in these training activities. An example of a User Interface tutorial on Ms. Excel can be seen in Figure 1 and Figure 2.

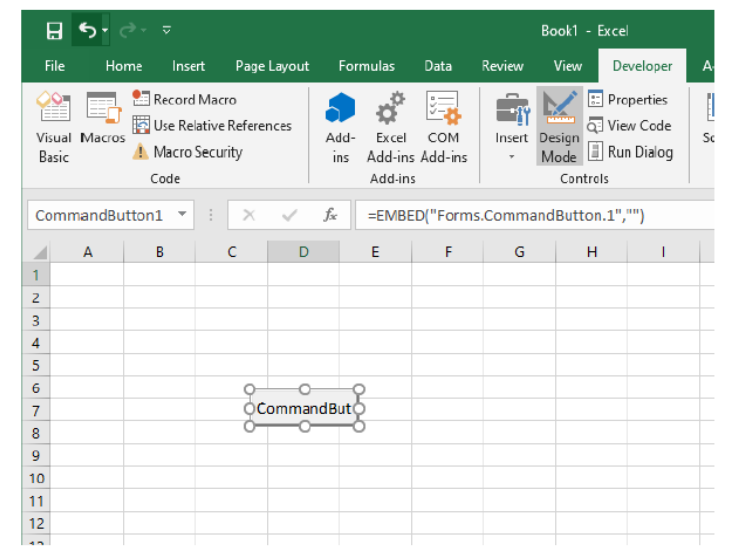

Figure 1. An example of the user interface in designing programming button

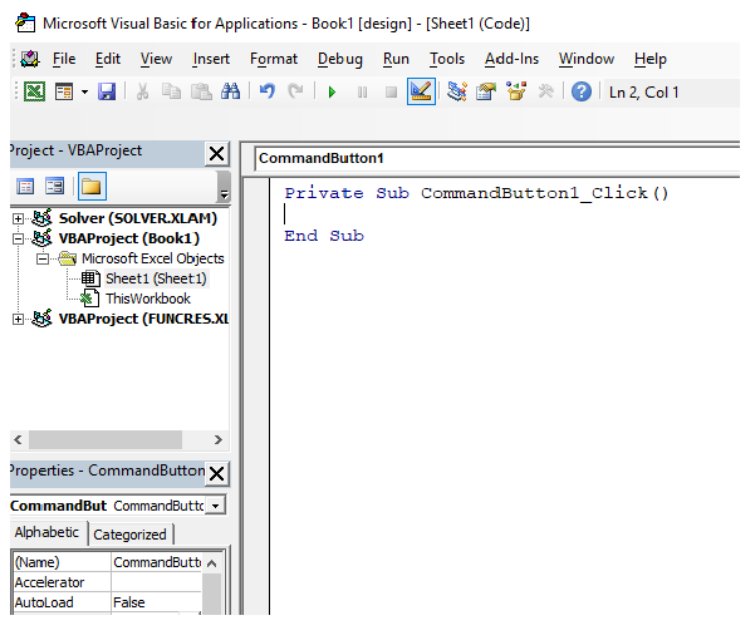

Figure 2. An example of code editor VBA-Ms. Excel 
There are four special materials (modules) in this VBA-Excel training which has a duration of 120 minutes for each section. The material starts from basic and simple features from VBA programming to the integration process of Ms. Excel with various complex features. The VBA-Ms.Excel course outline can be seen in Table 1.

Tabel 1. Outline Course VBA-Ms. Excel

\begin{tabular}{|c|c|c|c|}
\hline Module & Course Title & Learning Outcome & Duration \\
\hline Module 1 & $\begin{array}{l}\text { Input, Output, and } \\
\text { Expression }\end{array}$ & $\begin{array}{l}\text { - Participants are able } \\
\text { to understand } \\
\text { programming in the } \\
\text { VBA language } \\
\text { - Participants can } \\
\text { apply input/output } \\
\text { commands in the VBA } \\
\text { language which is } \\
\text { integrated with Ms. } \\
\text { Excel }\end{array}$ & 120 minutes \\
\hline Module 2 & $\begin{array}{l}\text { Decision and Looping } \\
\text { Processes }\end{array}$ & $\begin{array}{l}\text { - Participants can use } \\
\text { decision processes to } \\
\text { analyze decisions in } \\
\text { VBA language } \\
\text { - Participants are able } \\
\text { to apply the repetition } \\
\text { structure in } \\
\text { programming using } \\
\text { the VBA language }\end{array}$ & 120 minutes \\
\hline Module 3 & Sub and Function & $\begin{array}{l}\text { - Participants are able } \\
\text { to understand the } \\
\text { concept of modularity } \\
\text { - Participants can } \\
\text { create programs using } \\
\text { the sub and function } \\
\text { features }\end{array}$ & 120 minutes \\
\hline Module 4 & $\begin{array}{l}\text { Array and User- } \\
\text { Defined Type }\end{array}$ & $\begin{array}{l}\text { - Participants can } \\
\text { apply array variables } \\
\text { in VBA language } \\
\text { - Participants are able } \\
\text { to make programs } \\
\text { using User Defined } \\
\text { Type }\end{array}$ & 120 minutes \\
\hline
\end{tabular}

\section{RESULTS AND DISCUSSION}

VBA-Ms. Excel training activities take place on two days face to face and one day in the form of programming assignments. In addition, at the beginning and the end of the training, participants will be asked to complete a test which can later be used as a measure of the training outcomes.

\subsection{Introduction modules in the face to face online course (Day 1)}

The first day of the VBA-Ms. Excel training was held on August 30, 2020. On the first day, the materials consisted of two parts, namely introductory material related to input, output and expression, and the other core material related to decision and looping processes. These 
activities begin with a join online course processes and open at 07.00 to 08.00 , and it is continued with a pre-test to measure the participant ability at the start of the training. Pictures related to the opening and the pre-test can be seen in Figures 3, 4, and 5.

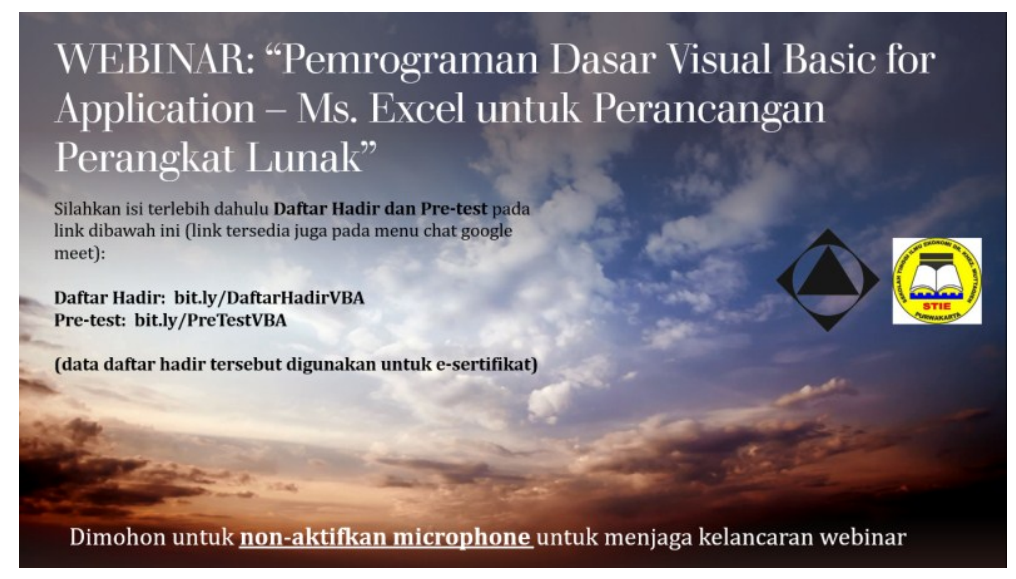

Figure 3. An example of online training-introduction slide

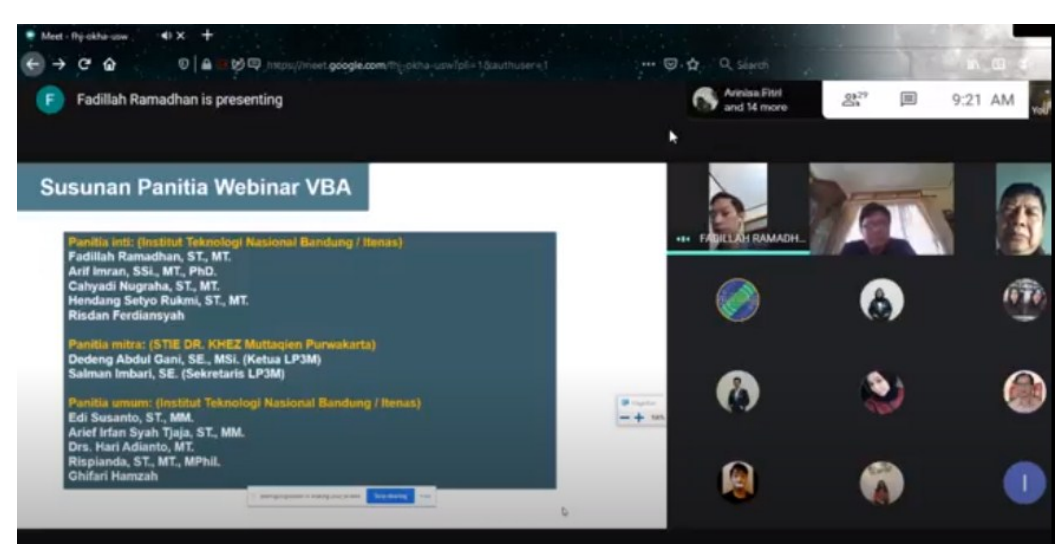

Figure 4. An example of online training interaction in google meet

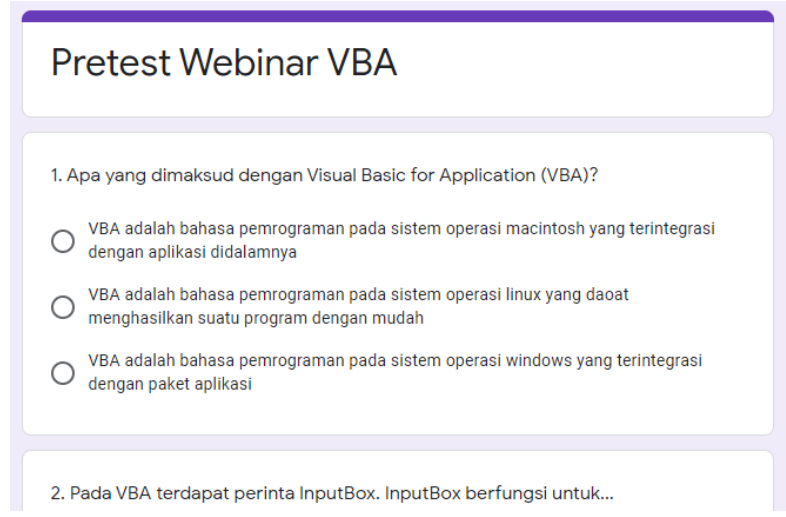

Figure 5. An example of pre-test VBA-Ms. Excel 
In the initial material of VBA-Ms. Excel, a team from the Department of Industrial Engineering, Institut Teknologi Nasional Bandung invited participants directly to the implementation process on Ms. Excel from the coding described. The first material is related to input, output, and expressions. Participants are given a tutorial directly on the screen using google meet, where participants can try it directly on their computer. This team is consisting of four people; there are Fadillah Ramadhan, ST., MT. (as the main tutor), Risdan Ferdiansyah, Arif Imran, S.Si. PhD., Cahyadi Nugraha, ST., MT., and Hendang Setyo Rukmi, ST., MT. An example of delivering material regarding input and output can be seen in Figure 6.

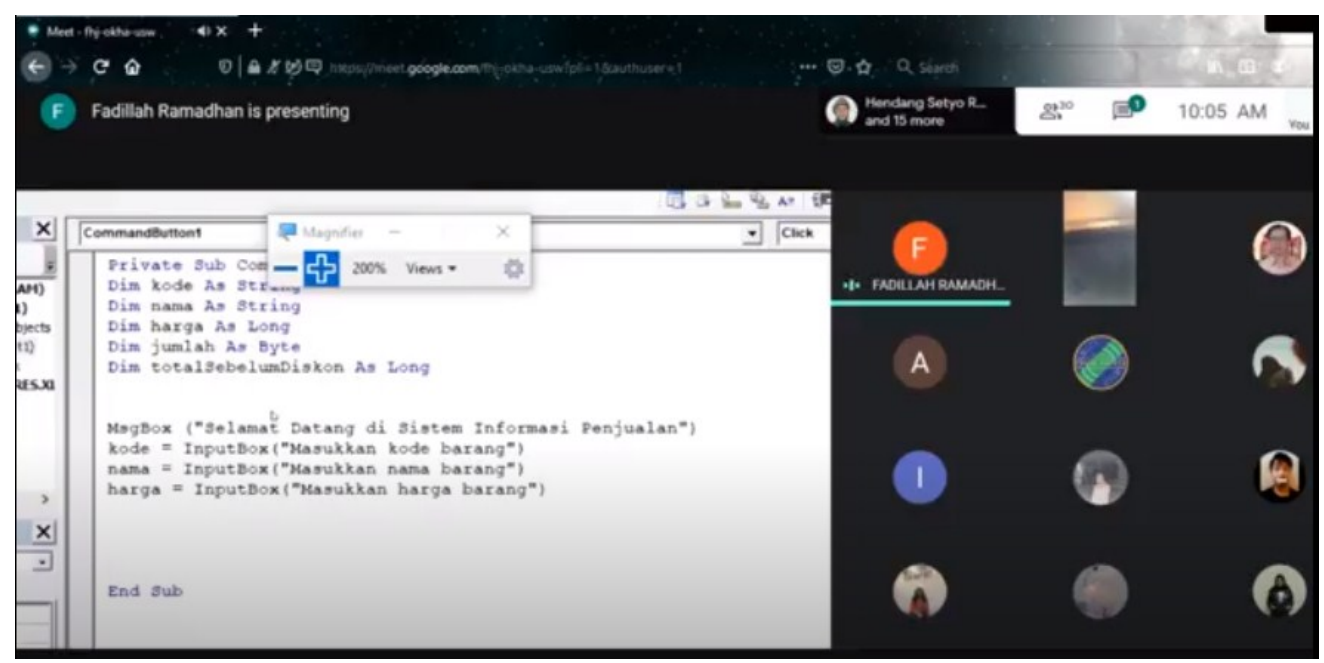

Figure 6. An example delivering input and output material in google meet

On the first day, the material topic is about the input and output process as well as some mathematical operations used to collect data on purchases of goods. In training, there is also a discount variable to increase the complexity of the program. Around 31 participants enthusiastically participated in the first day of training. Examples of program code that is taught and their appearance can be seen in Figures 7 and 8.

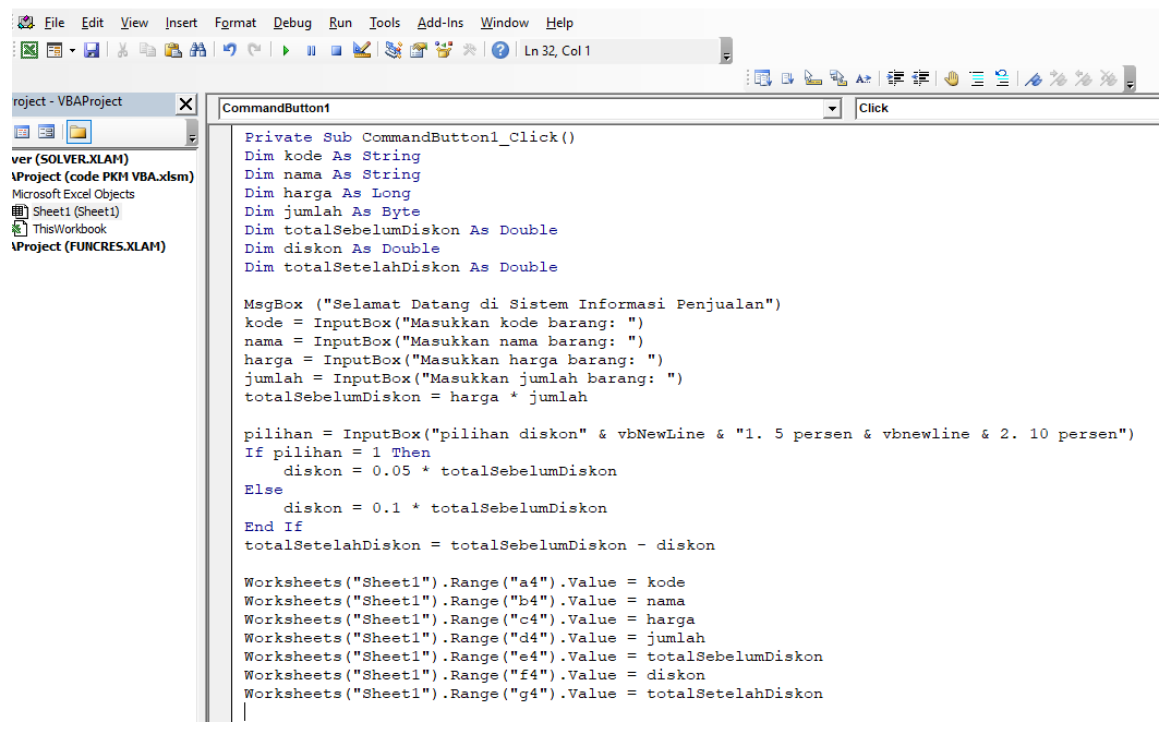


Figure 7. An example of code programming in VBA-Ms. Excel

\begin{tabular}{|c|c|c|c|c|c|c|c|c|}
\hline 4 & A & B & C & D & $\mathrm{E}$ & $\mathrm{F}$ & G & $\mathrm{H}$ \\
\hline 1 & \multicolumn{8}{|c|}{ Data Penjualan } \\
\hline \multicolumn{9}{|l|}{2} \\
\hline 3 & Kode Barang & Nama Barang & Harga Satuan & Jumlah & Total Sebelum Diskon & Total Diskon & Total Setelah Diskon & \\
\hline 4 & BR001 & Laptop & 8000000 & 2 & 16000000 & 800000 & 15200000 & \\
\hline 5 & & & & & CommandBut & & & \\
\hline 6 & & & & & & & & \\
\hline 7 & & & & & & & & \\
\hline 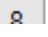 & & & & & & & & \\
\hline
\end{tabular}

Figure 8. An example of the output in VBA-Ms. Excel

3.2 Programming language assignment related to accounting system case (Day 2) At the end of the first day, students are asked to work on a case study that must be submitted on the second day. The online discussion forum remains open for students who want to ask the tutor about the case. This task is given to sharpen students' programming skills and become more proficient in solving various problems. An example of a given case can be seen in Figure 9.

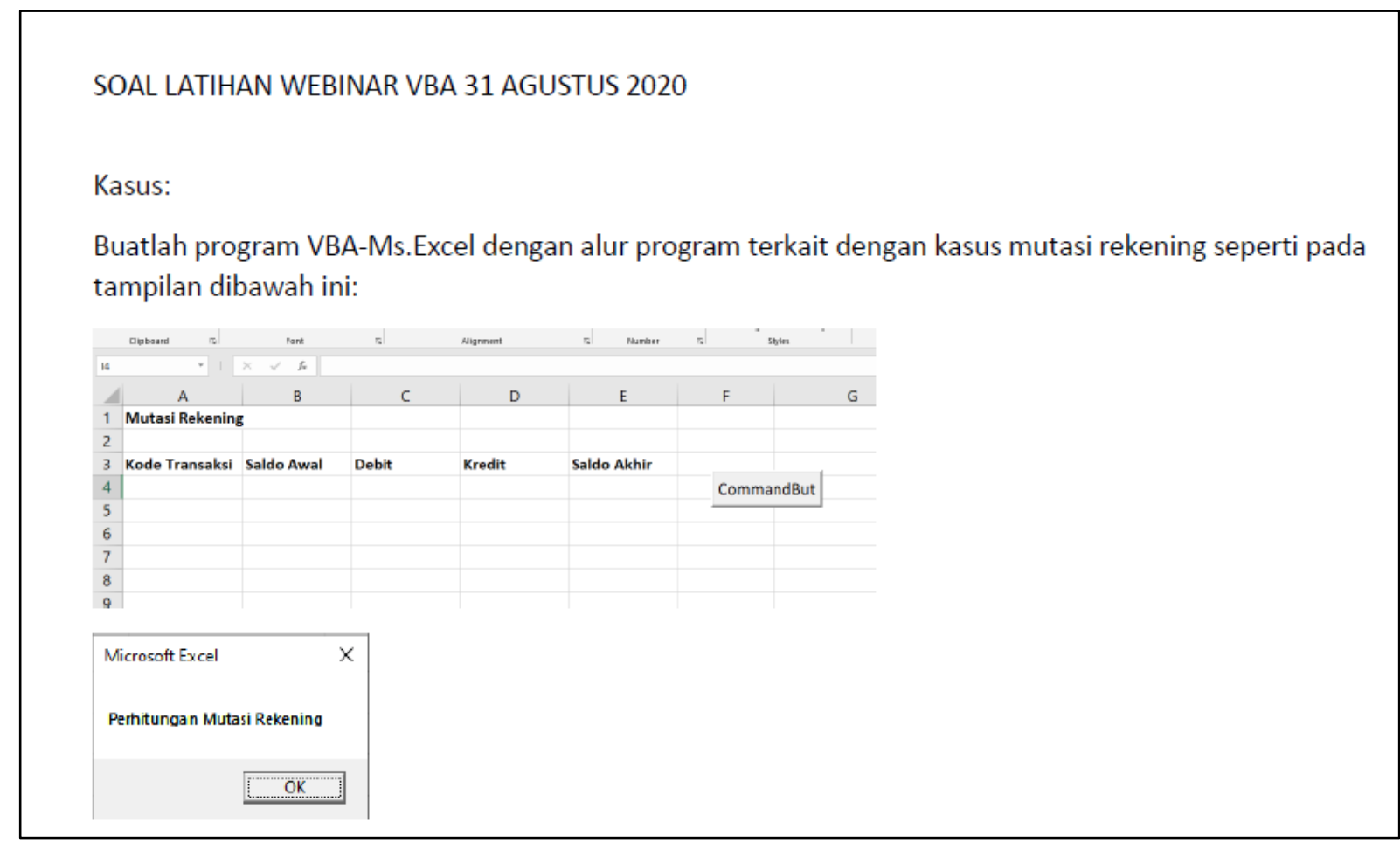

Figure 9. An example of a case study for students

Based on Figure 9, the case study topic is related to accounting case. Most of the students who participated in the webinar had a background in accounting education, so the cases given were related to accounting as well. This has a positive impact because the number of students who work on about 21 people or around $70 \%$ is excited about working on the 
Software Design using Visual Basic for Application and Microsoft Excel Programming for Students

questions and collecting them in the assigned assignment media, namely Google Classroom. The Google Classroom media used for assignment collection can be seen in Figure 10. 


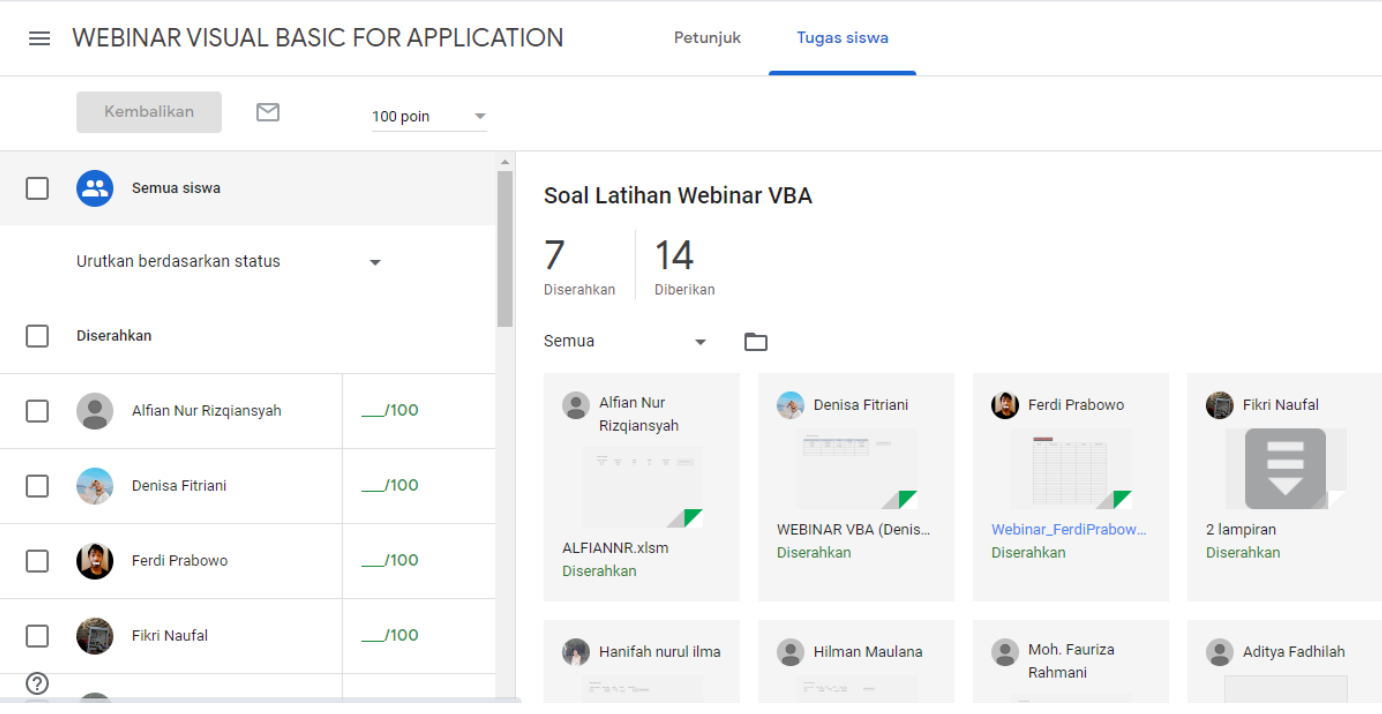

Figure 10. An example of google classroom assignment media in VBA-Ms. Excel training

\subsection{Final module of VBA-Excel (Day 3)}

On the last day, participants were given an advanced algorithm from a set of VBA features, namely Array and User Defined Type algorithms. An array is a variable where it consists of elements or members which function to store a number of data of the same type in one place. An example of common array variable declarations can be seen in figure 11 .

Dim Nama_Array (indeks_awal To indeks_akhir) As TipeData

Figure 11. An example of Array declaration in VBA

User-Defined Type (UDT) is a structured data type consisting of several elements where each element may have a different type of data type. UDT is made with a Type Statement where the declaration can be made in sheets, forms or in modules. The UDT declaration begins with the word type followed by a list of elements and ends with the word end type, which can be seen in Figure 12.

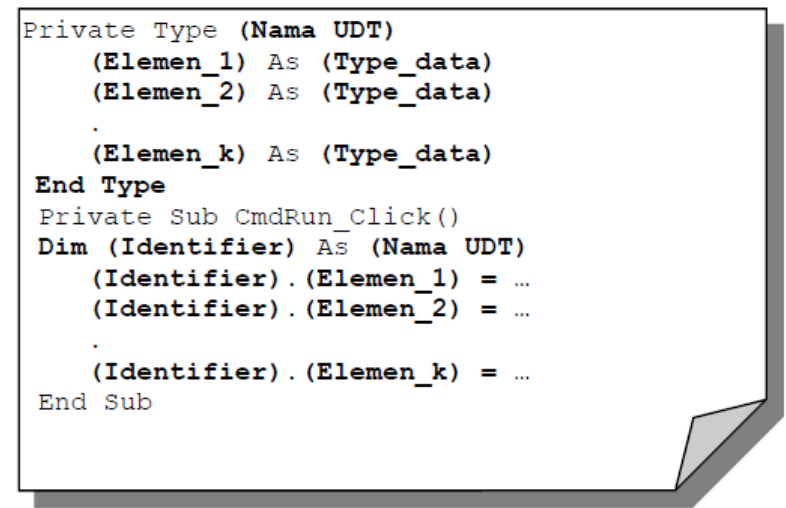

Figure 12. An example of a UDT declaration in VBA 
Software Design using Visual Basic for Application and Microsoft Excel Programming for Students

This third day of training went well with the number of participants that were approximately the same as the previous days. At the end of this activity as well as the closing of the training event, post-test and closing were carried out directly by the main tutor, and the event was over. An example of the online interface of this third day of learning can be seen in Figure 13 and 14.

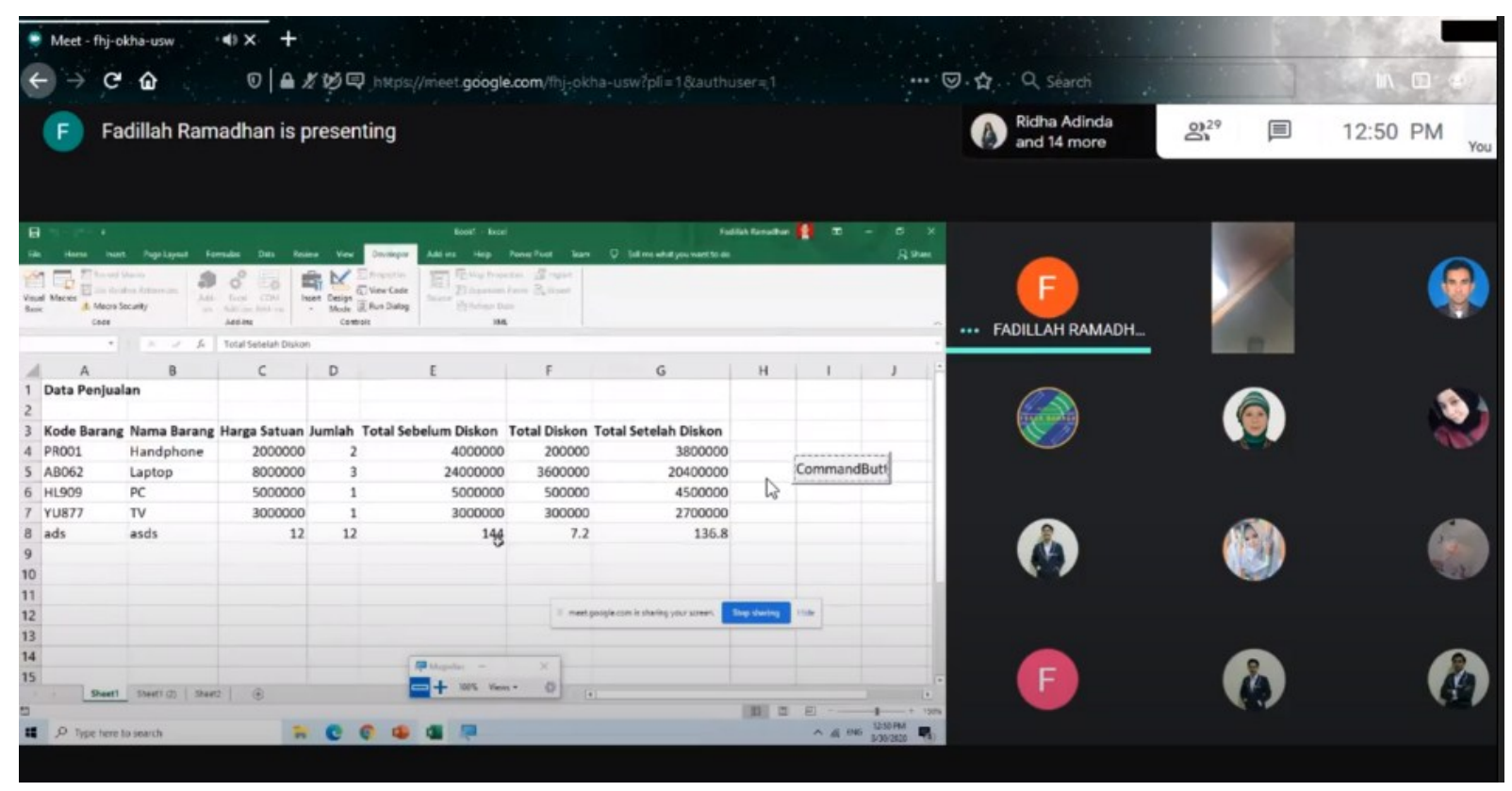

Figure 13. An example of the material in the last day training

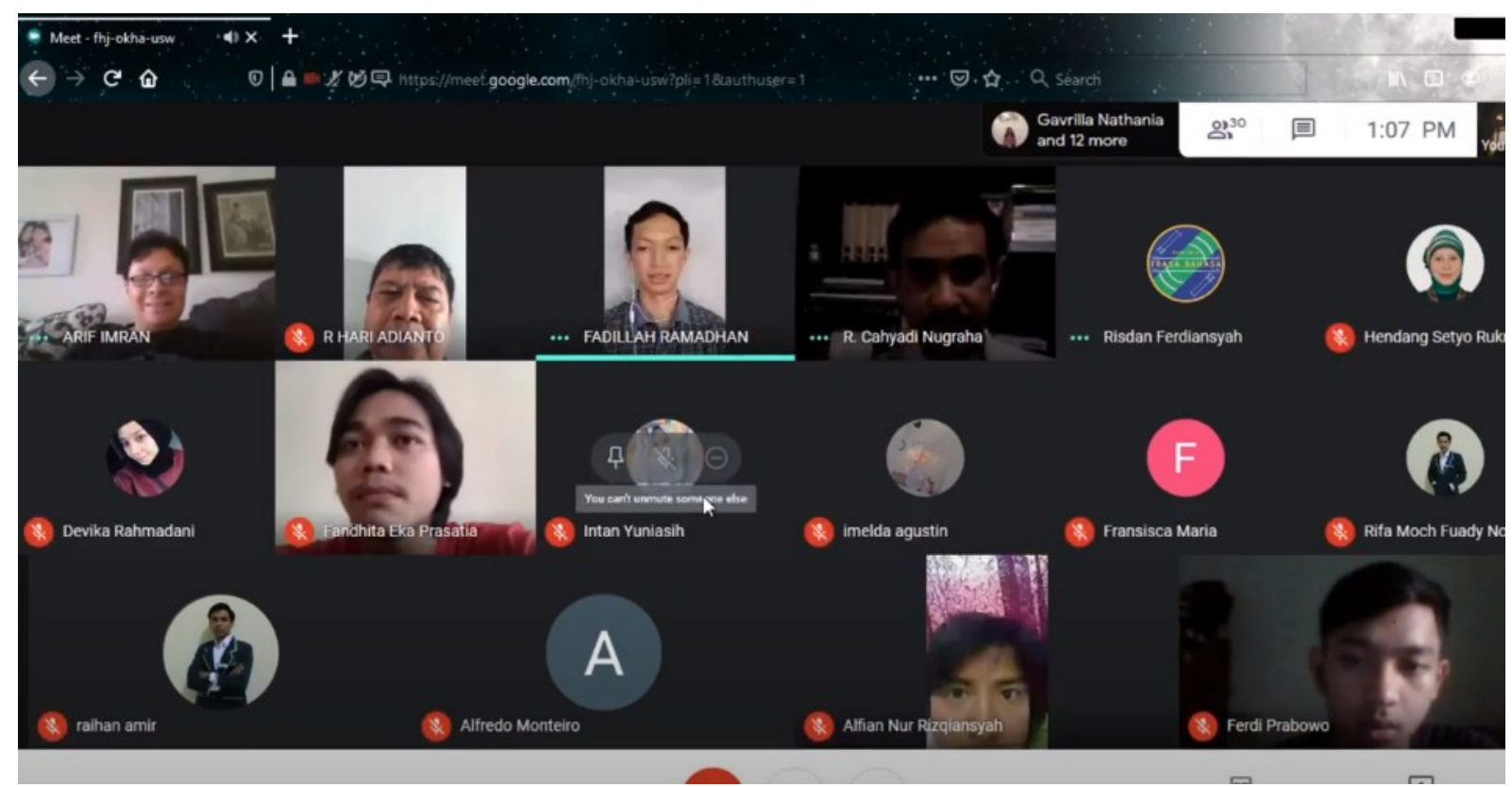

Figure 14. The last day online interaction of VBA-Ms. Excel Training 


\subsection{The result of the training test}

The results of this training test are measured through a comparison between the pre-test and post-test. The material being tested consists of the same questions, and it was submitted via google form for approximately 30 minutes. Each participant is required to take all of these tests as a condition for issuing an e-certificate. Almost all participants attended this three-day series of training activities. The comparison results of the pre-test and posttest can be seen in Table 2 and Figure 15.

Tabel 2. VBA-Ms. Excel training results from pre-test and post-test comparison

\begin{tabular}{|c|l|c|c|c|}
\hline No. & \multicolumn{1}{|c|}{ Name } & $\begin{array}{c}\text { Pre-test } \\
\text { Result }\end{array}$ & $\begin{array}{c}\text { Post-test } \\
\text { Result }\end{array}$ & $\begin{array}{c}\text { Percentage } \\
\text { Increase }\end{array}$ \\
\hline 1. & Devika Wulan Rahmadani & 14 & 14 & $00.00 \%$ \\
2. & Annisa Fitri & 15 & 15 & $00.00 \%$ \\
3. & Gavrilla Nathania & 15 & 15 & $00.00 \%$ \\
4. & Nur Aisyah Zahra & 8 & 10 & $\mathbf{2 5 . 0 0 \%}$ \\
5. & Raihan Amir Muhammad & 14 & 14 & $00.00 \%$ \\
6. & Denisa Fitriani & 11 & 13 & $\mathbf{1 8 . 1 8 \%}$ \\
7. & Fandhita Eka Prasatia & 13 & 15 & $\mathbf{1 5 . 3 8 \%}$ \\
8. & Rifa Moch. Fuady Noor & 10 & 12 & $\mathbf{2 0 . 0 0 \%}$ \\
9. & Ridha Nur Adinda Putri & 13 & 15 & $\mathbf{1 5 . 3 8 \%}$ \\
10. & Hilman Maulana & 9 & 11 & $\mathbf{2 2 . 2 2 \%}$ \\
11. & Ferdi Prabowo & 7 & 11 & $\mathbf{5 7 . 1 4 \%}$ \\
12. & Siti Fatimah Fitri Mulyani & 12 & 12 & $00.00 \%$ \\
13. & Hanifah Apriliani & 15 & 15 & $00.00 \%$ \\
14. & Annisa Yasmin Nurul K. & 15 & 15 & $00.00 \%$ \\
15. & Permata Aulia Juliani & 13 & 15 & $\mathbf{1 5 . 3 8 \%}$ \\
16. & Wishal Daffa A. & 12 & 15 & $\mathbf{2 5 . 1 4 \%}$ \\
17. & Alfian Nur Rizqiansyah & 13 & 13 & $00.00 \%$ \\
18. & Moh. Fauriza Rahmani W. & 14 & 14 & $00.00 \%$ \\
19. & Fina Aulia Alinda & 10 & 14 & $\mathbf{4 0 . 0 0 \%}$ \\
20. & Dinda Aura Khairunnisa & 11 & 11 & $00.00 \%$ \\
21. & Intan Yuniasih & 6 & 11 & $\mathbf{8 3 . 3 3 \%}$ \\
22. & Fransisca Maria & 13 & 15 & $\mathbf{1 5 . 3 8 \%}$ \\
23. & Naufal Ardiansyah & 14 & 14 & $00.00 \%$ \\
24. & Hanifah Nurul Ilma & 7 & 11 & $\mathbf{5 7 . 1 4 \%}$ \\
\hline
\end{tabular}

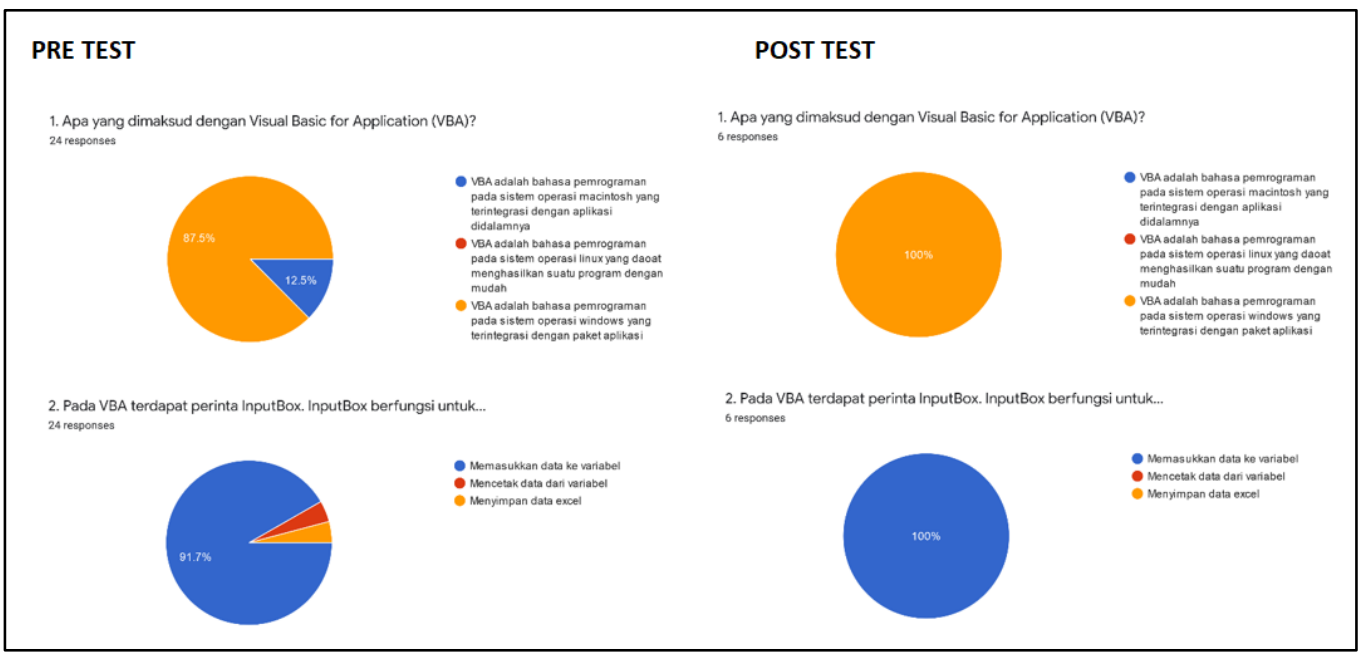

Figure 15. An example of differences between pre-test and post-test answers 
According to Table 2, it appears that more than 50 percent of the participants have better scores. The amount of the average increase in value between pre-test and post-test is $17.01 \%$. This is quite a significant increase considering that with a limited time of three days, the participants' knowledge of VBA-Ms. Excel is on the rise. Also, in Figure 15, you can see some examples of number 1 and 2 answers which are becoming increasingly uniform and correctly, this can also be used as evidence that the VBA-Ms. Excel training was useful for improving their programming skills.

\section{CONCLUSIONS}

Information technology is developing rapidly, and human resources Tare needed who are ready to face these challenges, especially competence in the use of programming languages. VBA-Ms. Excel training aims to help participants consisting of university students and vocational students as human resources who must be ready to face these technological challenges. Three days of training on the VBA-Ms. Excel programming language was executed and proved to be able to improve participants' abilities by $17.01 \%$. With this increase, it is hoped that the training can increase self-confidence and increase the desire to learn programming languages further. There are still some limitations in this training, such as limited time in explanation and difficulty in monitoring in detail for each participant due to the online implementation. For future development, assignment and explanation of existing features can still be increased in difficulty level and more comprehensive so that participants become more proficient in programming languages.

\section{ACKNOWLEDGEMENT}

The authors would like to thank Institut Teknologi Nasional Bandung for providing the funds for these training activities to be held. The authors thank STIE DR. KHEZ Muttaqien Purwakarta as a partner and host in organizing the participants who took part in this training activities.

\section{LIST OF REFERENCES}

Astuti, P. D. (2011). Sistem informasi penjualan obat pada Apotek Jati Farma Arjosari. Speed - Sentra Penelitian Engineering Dan Edukasi, 3(4), 34-39.

Cazzola, W., \& Olivares, M. (2016). Gradually learning programming supported by a growable programming language. Emerging Topics in Computing, 4(3).

Fisher, M. (1996). Integrating information technology: Competency recommendations by teachers for teacher training. Journal of Information Technology for Teacher Education, 5(3), 233-238.

Hyde, K. M., \& Maier, H. R. (2006). Distance-based and stochastic uncertainty analysis for multi-criteria decision analysis in Excel using Visual Basic for Application. Environmental Modelling \& Software, 21(12), 1695-1710.

Irmawati, D., \& Indrihapsari, Y. (2014). Sistem informasi kearsipan untuk meningkatkan kualitas pelayanan. Jurnal Pendidikan Teknologi Dan Kejuruan, 22(2). 
Li, X., Zhang, C., Almeev, R. R., \& Holtz, F. (2020). GeoBalanc: An Excel VBA program for mass balance calculation in geosciences. Geochemistry, $80(2)$.

Liu, H., Wei, S., Ke, W., Wei, K. K., \& Hua, Z. (2016). The configuration between supply chain integration and information technology competency: A resource orchestration perspective. Journal of Operation Management, 44, 13-29.

Nakic, Z., Posavec, K., \& Bacani, A. (2007). A visual basic spreadsheet macro for geochemical background analysis. Groundwater, 45(5).

Nasikin, K. (2011). Pengembangan sistem informasi akademis dan keuangan di MAN 2 Pati. Journal Speed, 3(3), 20-26.

Perez-Lopez, S., \& Alegre, J. (2012). Information technology competency, knowledge processes and firm performance. Industrial Management \& Data Systems, 112(4), 644-662.

Sa'ari, J. R., Luan, W. S., \& Samsilah, R. (2005). Attitudes and perceived information technology competency among teachers. Malaysian Online Journal of Instructional Technology, 2(3), 70-77.

Saputra, R. (2015). Desain sistem informasi order photo pada creative studio photo dengan menggunakan bahasa Visual Basic .NET 2010. Jurnal Momentum, 172), 86-93.

Sophan, S. (2014). Pengimplementasian dan perancangan sistem informasi penjualan dan pengendalian stok barang pada Toko Swastika Servis (SS) Bangunan dengan menggunakan bahasa Visual Basic 6.0 didukung dengan database MySQL. Jurnal Momentum, 16(2), 34-44.

Valipour, M., \& Montazar, A. A. (2012). Optimize of all effective infiltration parameters in furrow irrigation using Visual Basic and genetic algorithm programming. Australian Journal of Basic and Applied Sciences, 6(6), 132-137.

Wong, K. W. W., \& Barford, P. (2010). Teaching Excel VBA as a problem solving tool for chemical engineering core courses. Education for Chemical Engineers, 5(4). 